DOI:10.17951/h.2016.50.3.117

\begin{tabular}{lcc}
\hline \multicolumn{1}{c}{ A N N A L E S } \\
UNIVERSITATIS MARIAE CURIE-SKŁODOWSKA \\
LUBLIN - POLONIA \\
VOL. L, 3 & SECTIOH H \\
\hline
\end{tabular}

University of Szczecin. Faculty of Economics and Management

SEBASTIAN MAJEWSKI, AGNIESZKA MAJEWSKA

masaj@wneiz.pl,magnes@wneiz.pl

\title{
The Trinomial Tree and the PLC Theory in Footballers' Valuation
}

Wykorzystanie drzew trójmianowych i teorii cyklu życia produktu do wyceny piłkarzy

Keywords: valuation; players' performance rights; non-linear econometric models; trinomial three

Slowa kluczowe: wycena; karty zawodnicze; nieliniowe modele ekonometryczne; drzewa trójmianowe

JEL Code: G02; G12; L83

\section{Introduction}

The problem of the valuation of intangible assets in ordinary companies is very serious, but when it concerns untypical companies, valuation becomes more complicated. Sport companies are a small and very specialized group of enterprises having a very special type of intangible asset - a player's performance rights. Such assets require using adequate tools for the valuation process. The literature review indicates many different models used. There are, between the others, various econometric models, the trinomial tree and some option-based pricing methods.

There are not so many sports companies in the world and only a few of them are public companies. But the ones which are should keep their accounts under the regulations in force. Accounts require a thorough valuation of assets owned by the company. So, it is the first reason confirming the need to improve a footballer's performance rights valuation. Football agents are the most active participants in the football market. They are not only a party to the player's performance rights transaction, but they also can create a demand on this market. An effective agent can convince club managers of 
the usefulness of the footballer for the club. This group of market participants should be also interested in the proper valuation of players' performance rights because they make money on the transactions as interest on the amount of the transaction. The third group should be interested in the precise valuation of football players. This type of information could be also used in cases of sport arbitrage, when the parties of a sport contract are not agreed and there is a need to estimate lost profits.

The main goal of this article is to indicate the possibilities of using the product life cycle theory and trinomial tree method in a footballers' performance rights valuation process. The article should be treated as a case study using quantitative methods and objects for pricing the performance rights of three footballers: Wayne Rooney from Manchester United Football Club, Robert Lewandowski and Mario Götze both from Bayern Munich Football Club. The data is collected from web page transfermarkt. de in September 2015. Both econometric linear and non-linear models were used to test the best approximation of the life cycle curves. The shape of a curve suggests how to estimate the volatility to the trinomial tree.

\section{The product - football player}

Nowadays, many branches of human life are exposed to the influence of supply-demand formal relations. Such a situation concerns, among others, sport and culture. The commercialization of sport is closely tied with treating sport rivalry as a service, which causes money stream flows. Such a situation makes contemporary sport closer to an industry than the noble ideas of Baron de Coubertin. Until the 1990s, there was an artificial division of professional and amateur sport. Developed countries promoted professional sport clubs and socialist countries pretended that professional sport did not exist. In practice, enterprises had an obligation to financially support chosen clubs, in which players were theoretically employed in this enterprise. So, in both capitalist and socialist countries, sport was professional. The difference is that after changes in the political systems in Central and Eastern Europe, football clubs were not well prepared to function without state controlled support. The transfer market in the CEE countries before the 1990s was very limited - inside transactions were centrally controlled (officials could decide where a footballer should play) and external transactions were very rare (required to fulfil a number of conditions).

The real approach to the treatment of a football player as a product with his own brand, which gives the owner the possibility of making profits, causes that the buyer decides about his value (the price for the performance rights). Many football clubs have their own strategy regarding the training or recruiting of young players with the aim of selling them after some years. Such activity ensures that a club has a regular fixed source of income. The best example of this is Ajax Amsterdam, the first team being made up of 25 players with an average age of 23 years old. The balance of Ajax's transfers during the last 3 seasons is presented below in Table 1. 
Pobrane z czasopisma Annales H - Oeconomia http://oeconomia.annales.umcs.pl

Table 1. The balance of the transfer policy of Ajax Amsterdam over the last three seasons

\begin{tabular}{|l|l|c|c|}
\hline \multirow{2}{*}{ Season } & & $\begin{array}{l}\text { The number } \\
\text { of transfers }\end{array}$ & $\begin{array}{l}\text { The value of transfers } \\
\text { (millions EUR) }\end{array}$ \\
\hline \multirow{3}{*}{$2014 / 2015$} & Income & 15 & 28.5 \\
\cline { 2 - 4 } & Outcome & 17 & 12.8 \\
\cline { 2 - 4 } & Sum & -2 & 13.7 \\
\hline \multirow{3}{*}{$2013 / 2014$} & Income & 11 & 23.9 \\
\cline { 2 - 4 } & Outcome & 8 & 6.8 \\
\cline { 2 - 4 } & Sum & 3 & 17.1 \\
\hline \multirow{3}{*}{$2012 / 2013$} & Income & 17 & 32.7 \\
\cline { 2 - 4 } & Outcome & 17 & 5.7 \\
\cline { 2 - 4 } & Sum & 0 & 27.0 \\
\hline
\end{tabular}

Source: [transfermarkt.de].

As is presented in Table 1, the transfer policy of Ajax is concentrated on making profits from the sale of players. The average profits for the last three league seasons is EUR 19.3 million, compared with the average market value of the club in the same time period (EUR 84.3 million) gives the basis to conclude that Ajax's strategy is very effective.

There are also some clubs interested only in the most valuable players with branding to make profits on the sale of a player's image (kit, shirts and other saleable merchandise). Not every football brand though yields good returns. There are many players, especially at an age which indicates that the best of their football careers are behind them but they could still give experience and quality to a team. Their brand could not ensure good profits for a top club but it could be used by smaller teams in lower leagues. Such clubs offer good salaries for such players and they are clubs for them to retire at.

\section{The product life cycle}

The classical theory of the product life cycle was formulated by T. Levitt [1965] and it says that the success of every product on the market depends on the life cycle of this product and its total sale from the introduction to the decline phase, where the product is withdrawn from the market. The curve of sale in classical theories resembles an S-shape, describing the history of the sale of the product during a period of time. The classical version of the PLC curve is shown below in Figure 1.

Figure 1 presents four classic phases of a life cycle. The first one - introduction is characterized by the low level of sale. In our cases, it could mean low market value of the player but it is still growth. The second phase called growth is described by the fast increase of the market value of the footballer, joined with the creation of the player's brand. In this stage, the salary of the player starts the growth. This means that the costs of keeping a player starts to be significant. The maturity phase is the 


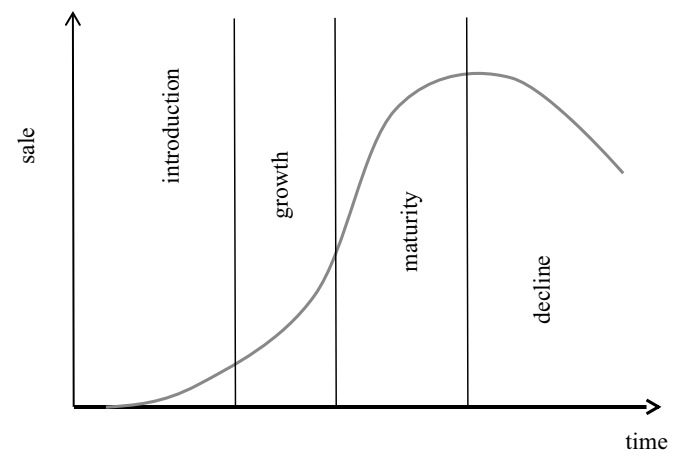

Figure 1. Phases of the product life cycle

Source: [Levitt, 1965].

main stage of a footballer's development both from the point of view players and clubs. The market value of the player is still growing and the brand starts to be more recognizable. The costs of employment are high and only the sale and advertising of merchandise can bring significant profits. From the mathematical point of view, maturity causes the market value to start slowing down after the curve's inflection point. The last stage of the product (player) life cycle is in the decline phase. This phase could have two possible routes: accelerated and slowed decline. In the case of players with high market values a slowed decline stage is often met, because of the brand value. An accelerated decline could be caused by different factors (for example the player's age or health condition).

Every player's performance history could be presented as a product, where it could be described by the PLC curve. Every stage in the life of a footballer is characterized by features similar to the original version [Kotler, Armstrong, 2012]. So, the stages of the life cycle of a typical product can be characterized, as follows:

a) introduction means the debut of the player into a professional league. This stage of the life cycle could be broken down into the following parts:

- scouting in lower leagues - looking for the player could fulfil the club's needs; the first contract conditions (salary, quota of payment of renunciation, etc.),

- picked for the first team - training with the first team and testing the footballer's position in the team,

- testing of the player in match-day conditions,

- decision about the footballer's future in the club.

The market value of the player grows very slowly as does his salary. The best advertisement for the footballer are his match performances. Acceptance of the supporters also has an impact on the extension of a contract;

b) growth means the situation when the player passed the introduction phase and he has been spotted by sports commentators, managers of other teams 
and sports agents. At this stage, managers could decide how to use the footballer for making additional profits for the club, but it is of course connected with a new better contract for the player. The value of the player grows, so managers jointly with agents could decide if the player is necessary for the team or if the profits from his transfer are more desired. This stage could also have a negative result. In such a situation the market value of the performance rights could move to the decline phase;

c) at the maturity stage, the goals of the player and his agent are different than the goals of the club. The return on the hypothetical transfer is not so big as in the growth phase and the contract obliges the club to pay a large salary to the player. So, the best strategy for the club's managers is to keep the player to the end of the contract and to use his brand to promote the club and make more profits by selling the image of the footballer;

d) the last phase is the decline stage. At this stage, the value of the footballer decreases and the costs of the contract start to exceed any potential profits. This phase can be the last one but there are some cases when the market value of the performance rights could rise. A significant factor is age and susceptibility to injuries.

\section{The methodology of the research}

The methodology used in the research is divided into two parts. The first one is connected to the estimation of the product life cycle curve and the second represents models of financial instrument valuation. According to this fact the research was conducted in two steps:

1. The first step - the econometric approximation of the PLC curve's shape [Majewski, 2015]. At this step, the analytical form of function for particular PLC stages are chosen and after parameter estimations. There are used for four kinds of functions: linear (1), power (2), exponential (3) and logarithmic (4). There are as follows:

$$
\begin{gathered}
V_{t}=+\beta \cdot t+u_{t} \\
V_{t}=\cdot t^{\beta} \cdot \xi_{t} \\
V_{t}=\cdot e^{\beta \cdot t \cdot \xi_{t}} \\
V_{t}=+\beta \cdot \ln (t)+\xi_{t}
\end{gathered}
$$

where:

$V_{t}$ - market value of the footballer's performance rights

$t$ - time

$+\beta$ - model's parameters

$u_{t}, \xi_{t}$ - random components 
Estimated models are used to find moments of changes of phases as the points of intersection of estimated equations. The periods of time for particular stages determined in this way are the basis for volatility estimation for step 2 .

2. The second step - the valuation of footballers' performance rights using the trinomial tree methodology [Turnau, Clark, Viney, 2005].

The trinomial and the binomial models were applied for the financial variable valuation for the first time by Boyle [Boyle, 1988; Boyle, Evnine, Gibbs, 1989; Johnson, 1987; Kamrad, Ritchken, 1991]. The trinomial model is similar to the binomial model but it has three jumps. The three-point jump assumes that the stock price can increase with the probability $p_{u}$, decrease with the probability $p_{d}$ and remain at the same level with the probability $p_{m}\left(p_{m}=p_{u}=p_{d}=1\right)$. The process could be presented by Figure 2 .

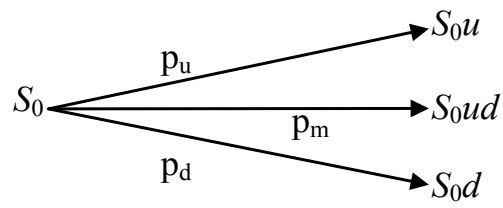

Figure 2. The three-point jump process for the value of the financial instrument

Source: [Majewska, 2013].

With note ${ }^{1}$ :
$p_{u}-$ the probability of an up movement: $p_{u}=\left(\frac{e^{r \Delta t / 2}-e^{-\sigma \sqrt{\Delta t / 2}}}{e^{\sigma \sqrt{\Delta t / 2}}-e^{-\sigma \sqrt{\Delta t / 2}}}\right)^{2}$

$p_{d}$ - probability of a down movement: $p_{d}=\left(\frac{e^{\sigma \sqrt{\Delta t / 2}}-e^{r \Delta t / 2}}{e^{\sigma \sqrt{\Delta t / 2}}-e^{-\sigma \sqrt{\Delta t / 2}}}\right)^{2}$

$u, d$ - percent of the increase and decrease of a stock price: $u=e^{\sigma \sqrt{2 \Delta t}}, d=e^{-\sigma \sqrt{2 \Delta t}}$

Parameter $\sigma$ (volatility) is estimated as the standard deviation calculated on the basis of m-months period (fixed in step 1). Due to the fact that every stage in the product life cycle is characterized by the different pace of change in the market value of a player, every stage has its own $\sigma$ parameter.

1 Boyle $\left[1988\right.$, p. 5] uses the note $u=e^{\lambda \sigma \sqrt{\Delta t}}$, where $\lambda$ is greater than 1 and is selected so that the probabilities are not negative. For $\lambda=1$ we obtain a binomial model. 


\section{Empirical examples}

The research is based on the market values of three footballers who are well known in the world. There are analysed cases of Robert Lewandowski, Wayne Rooney and Mario Götze. Their historical and present market values are taken from the German web site transfermarkt.de. The selection of cases had to show full or almost the full cycle of the footballer including the decline phase. Because of that, three footballers in different ages (being at different points on the PLC curve but minimum in the third phase) were taken into the research. Main characteristics of the analysed players are shown in Table 2.

Table 2. Sport characteristics of the chosen players (only league performance)

\begin{tabular}{|l|c|c|c|c|c|c|}
\hline \multicolumn{1}{|c|}{ Name of the player } & Age & $\begin{array}{c}\text { Number of } \\
\text { games played }\end{array}$ & $\begin{array}{c}\text { Number of } \\
\text { goals scored }\end{array}$ & $\begin{array}{c}\text { Number } \\
\text { of assists }\end{array}$ & $\begin{array}{c}\text { Total time on the } \\
\text { football pitch }\end{array}$ & $\begin{array}{c}\text { Market value } \\
\text { (millions EUR) }\end{array}$ \\
\hline Robert Lewandowski & 27 & 358 & 199 & 79 & 28,385 & 50 \\
\hline Wayne Rooney & 29 & 554 & 249 & 132 & $43,514^{\prime}$ & 40 \\
\hline Mario Götze & 23 & 263 & 87 & 78 & 18,339 & 45 \\
\hline
\end{tabular}

Source: [transfermarkt.de].

Table 2 presents the main characteristics of the analysed players. The most experienced player is Wayne Rooney, so it is very probable that his market value is in the last phase of the cycle. Two other players are in the third phase, so their careers could cause an increase of their values, especially in the case of Mario Götze because he is the youngest. The curve of the PLC was divided into four parts for every player. The R-square coefficients were a criterion for the selections: the length of the time period and the analytical form of the function. It means that the length of the observation series and the form of function were changed so long as the highest $\mathrm{R}$-square was obtained. The points of intersection of the obtained equations indicate the top and bottom limits of the time subseries. The standard deviations $(\sigma)$ were calculated for the obtained subseries.

Equations estimated for the market values of Robert Lewandowski are presented below in Table 3.

Table 3. The econometric models for Robert Lewandowski's PLC phases

\begin{tabular}{|l|l|c|c|c|}
\hline \multicolumn{1}{|c|}{ The phase } & \multicolumn{1}{c|}{ The model } & R-square & Subseries limits & $\sigma$ \\
\hline Introduction & $V_{t}=-0.4592+0.1784 \cdot t$ & 0.9603 & $\mathrm{t} \varepsilon(0 ; 38)$ & 0.585429 \\
\hline Growth & $V_{t}=0.5597 \cdot e^{0.0637 \cdot \mathrm{t}}$ & 0.9306 & $\mathrm{t} \varepsilon(38 ; 55)$ & 0.412053 \\
\hline Maturity & $V_{t}=10.434+11.368 \cdot \ln (t)$ & 0.8721 & $\mathrm{t} \varepsilon(55 ; 91)$ & 0.103859 \\
\hline
\end{tabular}

Source: own calculations.

The results indicate that the market value of Robert Lewandowski passed through the three stages. Just now it stays in the maturity phase and more probable is that the value will not change. Subseries limits were determined and on their base volatility 
were calculated. As it is shown in the Table, the highest value was obtained for the first stage (the market value was changed rapidly). The trinomial tree for the value of this player is presented on Figure 3.

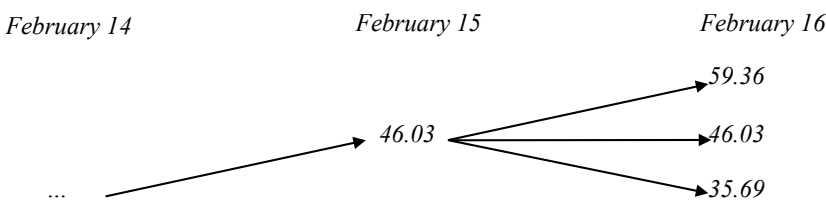

Figure 3. The last jump on the trinomial tree for Robert Lewandowski's market value (the hypothetical values for February 2016)

Source: own calculations.

Figure 3 presents a part of the trinomial tree of the pricing of Robert Lewandowski's performance rights. This part contains the last values in the more probable scenario and indicates the hypothetical market value for February 2016. The potential growth of the market value of this player will cause the change of the PLC's phase interpretation and change in the analytical form of the best approximating function. So, the growth could be higher than that presented in Figure 2.

Analogically, the PLC curves were estimated for the market values of Wayne Rooney. The results are shown in Table 4.

Table 4. The econometric models for Wayne Rooney's PLC phases

\begin{tabular}{|l|l|l|l|l|}
\hline \multicolumn{1}{|c|}{ The phase } & \multicolumn{1}{c|}{ The model } & \multicolumn{1}{c|}{ R-square } & \multicolumn{1}{c|}{ Subseries limits } & \multicolumn{1}{c|}{$\sigma$} \\
\hline Introduction & $V_{t}=32.321+0.1648 \cdot t$ & 0.8201 & $\mathrm{t} \varepsilon(6 ; 43)$ & 0.108620 \\
\hline Growth & $V_{t}=33.115 \cdot e^{0.0091 \cdot \mathrm{t}}$ & 0.9281 & $\mathrm{t} \varepsilon(43 ; 61)$ & 0.092379 \\
\hline Maturity & $V_{t}=30.003+8.2729 \cdot \ln (t)$ & 0.7661 & $\mathrm{t} \varepsilon(61 ; 102)$ & 0.126437 \\
\hline Decline & $V_{t}=73.901 \cdot \mathrm{t}-0.163$ & 0.7762 & $\mathrm{t} \varepsilon(102 ; 133)$ & 0.117039 \\
\hline
\end{tabular}

Source: own calculations.

The PLC of Wayne Rooney contains all the phases from the introduction to the decline. Similarly to Robert Lewandowski's PLC, the three first phases are described by the same type of analytical functions. The last stage - decline is described by the power function. Such a situation is called the slow decline, because the market values of the player decrease slower and slower. The second step of the research is presented in Figure 4.

This figure shows the most probable scenarios of changes in the price of Wayne Rooney's market value. According to the phase described above, the most probable change of the market value will be to the level of EUR 26.05 million. Because of the fact that this footballer is a legend at Manchester United Football Club, the club should have a special strategy for using his image and skills in the future. 


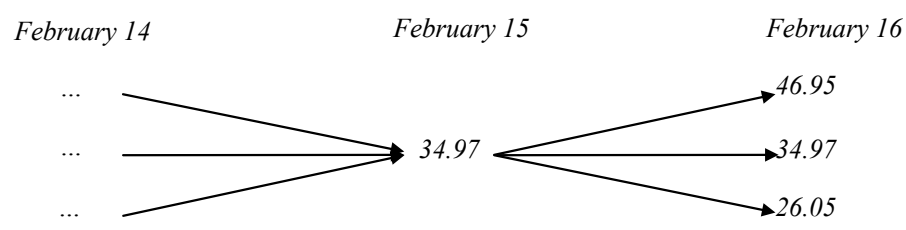

Figure 4. The last jump on the trinomial tree for Wayne Rooney's market value (hypothetical values for February 2016)

Source: own calculations.

The last case analysed in the article is the case of Mario Götze the so called "golden boy of German football" or the "German Messi". He is the youngest from the analysed players but his product life cycle indicates that all four phases have appeared. The equations of the PLC curves are presented in Table 5.

Table 5. The econometric models for Mario Götze's PLC phases

\begin{tabular}{|l|l|l|l|l|}
\hline The phase & The model & R-square & Subseries limits & $\sigma$ \\
\hline introduction & $V_{t}=0.3668 \cdot e^{0.0972 \cdot \mathrm{t}}$ & 0.8148 & $\mathrm{t} \varepsilon(1 ; 14)$ & 0.514138 \\
\hline growth & $V_{t}=1.3235 \cdot t^{0.9903}$ & 0.9558 & $\mathrm{t} \varepsilon(14 ; 43)$ & 0.437173 \\
\hline maturity & $V_{t}=25.875+8.6301 \cdot \ln (t)$ & 0.8194 & $\mathrm{t} \varepsilon(43 ; 60)$ & 0.327040 \\
\hline decline & $V_{t}=56.909-3.358 \cdot \ln (t)$ & 0.6230 & $\mathrm{t} \varepsilon(60 ; 75)$ & 0.262002 \\
\hline
\end{tabular}

Source: own calculations.

Similarly to the case of Robert Lewandowski, standard deviations are the highest in the first stages and smallest in the last stages. It is very interesting that this case shows all phases, despite that the footballer is not old in the meaning of professional sport (he is only 23). The rapid growth of his market value was caused by the media from the beginning. The media widely publicized information about a very talented young footballer named Mario Götze, so the natural result was the dynamic growth of his market value. But the sport career of this young midfielder did not develop as well as expected. Despite the fact that the PLC of this footballer has all the phases, less probable is that it is the end of his role in German football.

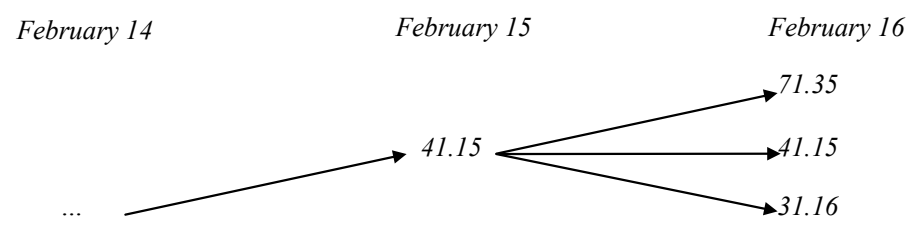

Figure 5. The last jump on the trinomial tree for Mario Götze's market value (hypothetical values for February 2016) 
On the basis of results from the last column, the market values of the most probable last jump were calculated (Figure 5).

The obtained results show that the case of Mario Götze is untypical. There are some possible scenarios of the development of his market value:

- the market value of this player is overvalued because of media activity - in such a scenario the value will still decline to the level of real value and from a new point, the next phases could be observed,

- the market value was fair but the sport value will not develop - in such a scenario a very slow decline should be observed,

- the player has a temporary crisis and his football career will cause the market value growth to be continued.

\section{Conclusions}

The approach joining two theories: the theory of product life cycle and the theory of option pricing. First of all, a footballer's performance rights should be treated as a financial product, so the PLC theory has a theoretical basis to be used in. The commercialization of sport and in particular football has forced professional football to change its original roles - football has become an industry, clubs - enterprises, players - products, the football match - the service and spectators - clients. Long serving football fans, loving their club and attached to the club's history, are treated as their own people and their behaviour is said to be fanatical. Nowadays, cash flow rules everything in the football industry.

Statistics and econometrics are very useful tools to be used in the management of the football industry. In the case of describing the product's life cycle's stages, they could play an important role. The possibilities of: 1) describing well the process of changes in values, 2) finding top and bottom limits of the cycle's phases, 3) identifying periods with different levels of volatility, are the major profits of using such tools.

The trinomial tree was presented as a supporting tool in the valuation of performance rights in 2005 [Turnau, Clark, Viney, 2005]. This approach shows how to use information about the life cycle's phase in the process of market value pricing. The necessity of taking the level of volatility (depending on the cycle's stage) into consideration in the valuation process was indicated in this research. The flexibility of the trinomial tree means that this method could be used in pricing with success.

\section{Bibliography}

Antonowicz D., Szlendak T., Kossakowski R., Pitkarz jako marka i preferencyjny kibic jako aborygen. O wybranych społecznych konsekwencjach komercjalizacji sportu, „Kultura i Społeczeństwo” 2012, nr 3. Antonowicz D., Szlendak T., Kossakowski R., Ostatni bastion antykonsumeryzmu? Kibice indywidualni w dobie komercjalizacji sportu, „Studia Socjologiczne” 2011, nr 3 (202). 
Boyle P.P., A Lattice Framework for Option Pricing with Two State Variables, "Journal of Financial and Quantitative Analysis" 1988, No. 23 (1), DOI: http://dx.doi.org/10.2307/2331019.

Boyle P.P., Evnine J., Gibbs S., Numerical Evaluation of Multivariate Contingent Claims, “The Review of Financial Studies" 1989, No. 2 (2), DOI: http://dx.doi.org/10.1093/rfs/2.2.241.

Carmichael F., Forrest D., Simmons R., The Labor Market in Association Football: Who Gets Transferred and for How Much?, "Bulletin of Economic Research" 1999, No. 51.

Frick B., The Football Players' Labor Market: Empirical Evidence from the Major European Leagues, "Scottish Journal of Political Economy" 2007, Vol. 54, No. 3,

DOI: http://dx.doi.org/10.1111/j.1467-9485.2007.00423.x.

Gerrard B., Dobson S., The Determination of Transfer Fees in English Nonleague Football, "Applied Economics" 2000, Vol. 32, No. 9.

Johnson H., Options on the Maximum or the Minimum of Several Assets, "Journal of Financial and Quantitative Analysis” 1987, No. 22 (3), DOI: http://dx.doi.org/10.2307/2330963.

Kamrad B., Ritchken P., Multinomial Approximating Models for Options with k-State Variables, "Management Science" 1991, No. 37 (12), DOI: http://dx.doi.org/10.1287/mnsc.37.12.1640.

Kesenne S., The Peculiar International Economics of Professional Football in Europe, "Scottish Journal of Political Economy" 2007, Vol. 54, No. 3, DOI: http://dx.doi.org/10.1111/j.1467-9485.2007.00421.x.

Kotler P., Armstrong G., Principles of Marketing, Pearson Prentice Hall, New Jersey 2012.

Levitt T., Exploit the Product Life Cycle, "Harvard Business Review" 1965, No. 43.

Lucifora C., Simmons R., Superstar Effects in Sport. Evidence from Italian Soccer, "Journal of Sports Economics" 2003, Vol. 4, No. 1, DOI: http://dx.doi.org/10.1177/1527002502239657.

Majewska A., Binomial and Trinomial Model in Valuating Employee Stock Options, "Actual Problems of Economics" 2013, Vol. 2, No. 1.

Majewski S., Wykorzystanie teorii cyklu życia produktu do szacowania wartości kart zawodniczych wybranych polskich pitkarzy, „Annales UMCS. Sectio H” 2015, Vol. 49, z. 4.

Mikołajczyk A., Rynek transferowy w piłce nożnej. Doświadczenia europejskie, „Studia Gdańskie. Wizje i Rzeczywistość" 2011, t. VIII.

Prabucki B., Gry sportowe jako element wzmacniający współczesne tożsamości etniczne. Analiza na przykładzie Basków, "Homo Ludens" 2012, nr 1 (4).

Sloane P., The Economics of Professional Football, "Scottish Journal of Political Economy" 1971, Vol. 18 (2).

Sznajder J., Charakterystyka rynku sportu profesjonalnego, „Gospodarka Narodowa” 2007, nr 10.

Sznajder A., Marketing sportu, PWE, Warszawa 2015.

Trequattrini R., Lombardi R., Nappo F., The Evaluation of the Economic Value of Long Lasting Professional Football Player Performance Rights, "WSEAS Transactions on Business and Economics" 2012, Vol. 9, Issue 4.

Turnau R., Clark E., Viney H., An Option Pricing Framework for Valuation of Football Players, "Review of Financial Economics" 2005, No. 14.

\section{Wykorzystanie drzew trójmianowych i teorii cyklu życia produktu do wyceny piłkarzy}

Obecnie piłka nożna to nie tylko sport amatorski, ale przede wszystkim dobrze rozwijająca się branża przemysłu. W związku z tym kluby piłkarskie zaczęły odgrywać podobną rolę, jak spółki prawa handlowego, z tą różnicą, że posiadają bardzo ważne, specyficzne aktywa niematerialne i prawne, jakimi są karty zawodnicze. Każdego roku tysiące graczy jest przedmiotem transferów pomiędzy klubami (w 2013 r. odnotowano 12 tys. transferów na ogólną kwotę przekraczającą 37 mld dolarów). Oznacza to, że monitorowanie wartości kart może pomóc w zabezpieczeniu klubu przed ryzykiem nieoczekiwanego spadku ich wartości.

Artykuł wskazuje możliwości wykorzystania metod ilościowych w monitorowaniu wartości kart zawodniczych. Autorzy postawili hipotezę, że połączenie metod drzew trójmianowych i cyklu życia pro- 
duktu może dać menadżerom dodatkowe narzędzia do zarządzania spółkami prowadzącymi działalność sportową. Drzewa trójmianowe są zwykle wykorzystywane do wyceny opcji, ponieważ dają możliwość poruszania się ceny po trzech ścieżkach z odpowiednim prawdopodobieństwem. W tym podejściu metoda jest wykorzystywana do ustalania przyszłych hipotetycznych wartości kart zawodniczych. Wykorzystanie cyklu życia produktu pomaga $\mathrm{w}$ analizie momentów zmian poszczególnych faz cyklu życia piłkarza, co skutkuje zmianami np. w tempie wzrostu wartości. W tej części opracowania wykorzystano nieliniowe modele ekonometryczne - najlepiej aproksymujące zmiany tych wartości.

$\mathrm{W}$ pracy wykorzystano dane historyczne pochodzące $\mathrm{z}$ serwisu trasfermarkt.de. W celu wykonania analiz obejmujących wszystkie możliwe przypadki wybrano trzy rodzaje piłkarzy: w fazie wzrostu, stabilizacji i spadku. Takie założenie spowodowało konieczność wyboru zawodników o odpowiednich cechach. W artykule zostały zaprezentowane zarówno możliwości, jak i wady takiego podejścia.

\section{The Trinomial Tree and the PLC Theory in Footballers' Valuation}

Nowadays, football is not just only an amateur sport, but also a big and a very interesting branch of industry for investors and gamblers. Football clubs start to act like an ordinary company on the market. One of the most important assets in a club's balance are footballers' performance rights. Every year thousands of players are the subject of football club transfers (in 2013 there were over 12.000 of such transfers with a total value of over USD 37 billion). It means that the monitoring of a footballer's value could protect a club before the risk of a sudden disadvantageous change.

This article indicates the possibilities of using quantitative methods in players' performance rights value monitoring. Authors have raised the hypothesis that joins methods of the trinomial tree and the product life cycle that could give the managers of clubs more powerful tools in managing a football club company. The trinomial tree is usually used to value the option price giving three paths of price movement. In this approach, the method was used to determine the future hypothetical value of footballers' performance rights. Using the product life cycle we could observe and analyse the moment in the life cycle of a football player. In this part of the research, non-linear models were used to approximate the best-fitting function of the market value of a player. Such information indicates the direction of movement on the trinomial tree.

In this article, we use the historical data of the market values of chosen football players from the web site http://transfermarkt.de. To make a proper analysis, we chose three kinds of players: in the phase of growth, in the phase of stabilization and the phase of dropping down in value. Such an assumption causes the necessity of choosing players with adequate features, for example: age, skills and the team played for. Therefore, the length of the time series depends on the years and the performances of the footballer. The opportunities and threats of such an attempt are shown in this article. 